\title{
Lyotropic Liquid Crystalline Mesophases Made of Salt-Acid- Surfactant Systems for the Synthesis of Novel Mesoporous Lithium Metal Phosphates
}

\author{
Işıl Uzunok, ${ }^{[a]}$ Jeonghun Kim, ${ }^{[b, c]}$ Tuluhan O. Çolak, ${ }^{[a]}$ Dae Sik Kim, ${ }^{[d]}$ Hansu Kim, ${ }^{[d]}$ \\ Minjun Kim, ${ }^{[c]}$ Yusuke Yamauchi, ${ }^{[b, c, e]}$ and Ömer Dag ${ }^{*[a, f]}$
}

\begin{abstract}
Mesoporous lithium metal phosphates are an important class of materials for the development of lithium ion batteries. However, there is a limited success in producing mesoporous lithium metal phosphates in the literature. Here, a lyotropic liquid crystalline (LLC) templating method was employed to synthesize the first examples of $\mathrm{LiMPO}_{4}$ (LMP) of $\mathrm{Mn}(\mathrm{II}), \mathrm{Co}(\mathrm{II})$, and $\mathrm{Ni}$ (II). A homogeneous aqueous solution of lithium and transition metal nitrate salts, phosphoric acid (PA), and surfactant (P123) can be spin coated or drop-cast coated over glass slides to form the LLC mesophases which can be calcined into mesoporous
\end{abstract}

amorphous LMPs (MA-LMPs). The metal salts of Mn(II), Co(II) and $\mathrm{Ni}(\mathrm{II})$ produce MA-LMPs that crystallize into olivine structures by heat treatment of the LLC mesophase. The Fe(II) compound undergoes air oxidation. Therefore, both $\mathrm{Fe}(\mathrm{II})$ and $\mathrm{Fe}(\mathrm{III})$ precursors produce a crystalline $\mathrm{Li}_{3} \mathrm{Fe}_{2}\left(\mathrm{PO}_{4}\right)_{3}$ phase at over $400^{\circ} \mathrm{C}$. The MA-LMPs show no reactivity towards lithium, however the crystalline iron compound exhibits electrochemical reactivity with lithium and a good electrochemical energy storage ability using a lithium-ion battery test.

\section{Introduction}

Mesoporous silicate was discovered more than 25 years ago $^{[1,2]}$ and has been explored extensively in order to fully control on its structure and morphology. Currently, several methods to synthesize mesoporous silica with various structures and morphologies ${ }^{[5-8]}$ are available. A similar effort has also been devoted to periodic mesoporous organosilicates ${ }^{[9]}$ and titania. ${ }^{[10]}$

[a] I. Uzunok, T. O. Çolak, Prof. Ö. Dag

Department of Chemistry

Bilkent University

06800 Ankara (Turkey)

E-mail: dag@fen.bilkent.edu.tr

[b] Dr. J. Kim, Prof. Y. Yamauchi

Key Laboratory of Eco-Chemical Engineering

College of Chemistry and Molecular Engineering

Qingdao University of Science and Technology

Qingdao 266042 (P. R. China)

[c] Dr. J. Kim, M. Kim, Prof. Y. Yamauchi

School of Chemical Engineering

and Australian Institute for Bioengineering

and Nanotechnology (AIBN)

The University of Queensland

Brisbane, QLD 4072 (Australia)

[d] Dr. D. S. Kim, Prof. H. Kim

Department of Energy Engineering

Hanyang University

Seoul 133-791 (Republic of Korea)

[e] Prof. Y. Yamauchi

International Center for Materials Nanoarchitectonics (WPI-MANA)

National Institute for Materials Science (NIMS)

1-1 Namiki, Tsukuba, Ibaraki 305-0044 (Japan)

[f] Prof. Ö. Dag

UNAM-National Nanotechnology Research Center

and Institute of Materials Science and Nanotechnology

Bilkent University

06800 Ankara (Turkey)

Supporting information for this article is available on the WWW under https://doi.org/10.1002/cplu.201900435

There have been also many preparation methods to produce mesoporous metal oxides $^{[10]}$ by hard- ${ }^{[11]}$ or soft-templating ${ }^{[12]}$ approaches. However, there are few methods to synthesize metal chalcogenides, ${ }^{[13]}$ metal phosphates, ${ }^{[14-16]}$ and metal sulphates ${ }^{[17]}$ which are highly important for applications in energy production and storage. ${ }^{[14-22]}$ To fully understand and control the properties of these materials, many efforts must be undertaken. Recent investigations show that mesoporous materials (MMs) have many advantages in energy generation, conversion, and storage. ${ }^{[16-22]}$ MMs offer many advantages over their bulk counterparts, such as high surface area, size effects (both electronic and thermodynamic), reactivity in confined space, better electronic and ionic conductivity. ${ }^{[23-27]}$

Mesoporous metal phosphates (MMPs) are important in energy applications. Many transition metal phosphates are as good candidates as cathode materials in lithium ion batteries or supercapacitors. ${ }^{[16,28-32]}$ However, the synthesis of mesoporous lithium metal phosphates (LMPs) is still a big challenge. A fast reaction between the metal ion precursors and phosphate ions in the solution phase yields large crystallites that are impossible to assemble into mesostructures by surfactants or micelles. A good kinetic control, during the formation of the LMPs, is necessary in order to develop the desired morphology and pore systems. Optimal kinetic control in the assembly process may have a positive impact on the development of high power energy storage systems. ${ }^{[33,34]}$ There are still limited number of synthetic methods for the successful synthesis of mesoporous metal phosphates (MMPs) and none for the LMPs in the literature. ${ }^{[14,16,31,32,35-38]}$ However, there have been attempts to control the formation kinetics in these processes using substituted phosphates. ${ }^{[14,37]}$ The metal phosphate formation kinetics and self-assembly kinetics need to be adjusted to expand the possibilities of MMPs and LMPs for their use in 
energy applications. A good kinetic control may be achieved by reducing/controlling the phosphate $\left(\mathrm{PO}_{4}{ }^{3-}\right)$ ion concentration in the synthesis to control the metal phosphate formation and enhancing the micelle formation to increase the speed of the assembly process.

Here, we show that a better kinetic control over the metal phosphate formation could be achieved using phosphoric acid (PA, weak acid) as a phosphate source and by introducing lyotropic anions (such as phosphate related ions, $\mathrm{H}_{2} \mathrm{PO}_{4}^{-}$, $\mathrm{HPO}_{4}{ }^{2-}$, and $\mathrm{PO}_{4}{ }^{3-}$ ) for the assembly of surfactant molecules into micelles. ${ }^{[15,16]}$ PA-non-ionic surfactant ${ }^{[39]}$ and salt-non-ionic surfactant mesophases ${ }^{[40-42]}$ are all important in the process and need further exploration. Here, we show that salt-PA-surfactant mesophases can be used as a media to synthesize mesoporous LMP powders in various morphologies. Four different transition metal precursors (nitrate salts of $\mathrm{Mn}$ (II), $\mathrm{Fe}(\mathrm{II}), \mathrm{Co}(\mathrm{II})$ and $\mathrm{Ni}(\mathrm{II})$ ) and lithium salts $\left(\mathrm{LiNO}_{3}\right.$ and $\left.\mathrm{LiH}_{2} \mathrm{PO}_{4}\right)$ and $\mathrm{P} 123$ have been employed to develop a general method to obtain the mesoporous lithium metal phosphates (MLMPs).

\section{Results and Discussion}

\section{PA-P123 Mesophases}

$\mathrm{PA}-\mathrm{C}_{12} \mathrm{E}_{10}\left(\mathrm{C}_{12} \mathrm{EO}_{10}\right.$ is 10-lauryl ether) surfactant mesophase is known in the literature. ${ }^{[39]}$ This work investigates, for the first time, the formation of LLC mesophase of PA-P123, a mixture of $\mathrm{PA}$ and P123, over a broad range of PA/P123 mole ratios, from 10 to 100 . Coating of a clear aqueous solution of PA and P123 produces a clear gel, and a gelation happens upon complete evaporation of the excess water within a few minutes to hours, depending on the thickness. The gels, in all compositions, diffract at small angles. Figure 1 shows small angle XRD patterns of 10PA-P123 and 20PA-P123 and ATR-FTIR spectra of 10,30, 60 , and 90 PA/P123 mole ratio PA-P123 mesophases (numbers are PA/P123 mole ratio). The gels, spread over glass slides, display intense diffraction lines at low PA/P123. The samples of 10 up to 30PA-P123 are highly ordered/oriented, such that the 20PA-P123 displays up to 8 diffraction lines that can be indexed to a cubic mesostructure with a unit cell parameter $a$ of $108.9 \AA$. However, the order is lost at higher acid concentrations (over 30 up to $100 \mathrm{PA} / \mathrm{P} 123$ ) and only the (100) line and broader diffractions lines at higher angles are present in the XRD patterns.

ATR-FTIR spectra of the gels (PA-P123) display two sharp peaks at 978 and $471 \mathrm{~cm}^{-1}$ due to anti-symmetric stretching and bending modes of PA in the gel phase, respectively. The tail to lower energy of the peak at $978 \mathrm{~cm}^{-1}$ is likely due to symmetric stretching of the PA in the media, showing the interaction of PA with water and P123. The peaks at 1007 and $488 \mathrm{~cm}^{-1}$, observed in 10PA-P123 gradually red-shift by 30 and $17 \mathrm{~cm}^{-1}$, respectively, by increasing the $\mathrm{PA} / \mathrm{P} 123$ mole ratio from 10 to 90 and some changes in the surfactant related peaks (broadening in the $v-\mathrm{CH}$ stretching modes around 2800$3000 \mathrm{~cm}^{-1}$ and $\delta-\mathrm{CH}_{2}$ around $1250-1500 \mathrm{~cm}^{-1}$ and a red-shift by $30 \mathrm{~cm}^{-1}$ in the $v$-CO stretching modes) are observed. The
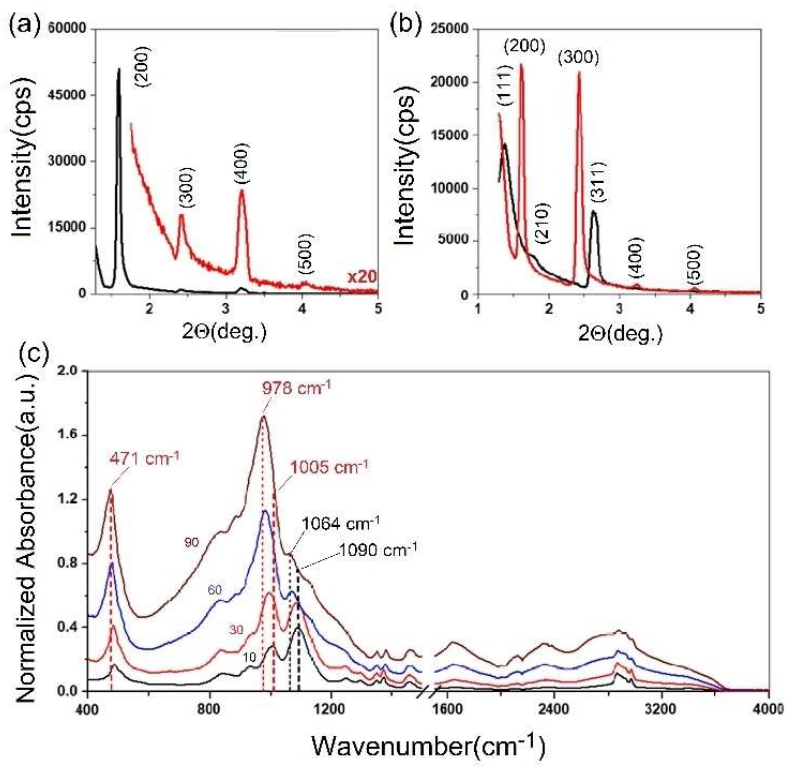

Figure 1. XRD patterns of \#PA-P123 mesophases, where \# is (a) 10 and (b) 20 (black line is fresh and red line is aged samples). (c) ATR-FTR spectra of \#PAP123 mesophases, \# is 10, 30, 60, and 90 as indicated in the spectra.

peaks due to the $\mathrm{P}-\mathrm{OH}$ and water (both stretching and bending) are extremely broad and the stretching mode of water is quite red-shifted, indicating that the water species are highly protonated and are strongly interacting with the surfactant moiety. The $\delta-\mathrm{P}-\mathrm{O}-\mathrm{H}$, bending mode, appears as a broad feature tailing from 850 to $650 \mathrm{~cm}^{-1}$. These spectral changes indicate strong interactions between the water and PA and between the water-PA and P123 in the gel-phase to form stable mesophases in such broad PA/P123 mole ratios.

\section{Lyotropic Liquid Crystalline Mesophases}

The salt-P123 systems of $\mathrm{Li}(\mathrm{I}), \mathrm{Zn}(\mathrm{II}), \mathrm{Cd}(\mathrm{II})$, and $\mathrm{Co}(\mathrm{II})$ salts have also been previously investigated. ${ }^{[40,41]}$ However, the $\mathrm{LiH}_{2} \mathrm{PO}_{4}{ }^{-}$ P123, Fe(II)-P123, Mn(II)-P123, Ni(II)-P123 and Li(I)-M(II)-PA-P123 mesophases were investigated for the first time in the content of this work. Establishing the lyotropic liquid crystalline (LLC) mesophases of individual salt-P123, PA-P123, and a mixture of salts-acid-surfactants are important to establish a background information for this work. The salts-P123 and PA-P123 mesophases are stable for a long time both in the solution phase and in the LLC mesophase. However, combining phosphate and metal precursors initiates the formation of metal phosphates, where the LLC phase slowly transforms to a disordered mesostructured solid. Therefore, the salt-P123 and PA-P123 solutions were prepared separately and then mixed prior to synthesis of mesostructured metal phosphates. It is also important to note that the $\mathrm{Li}(\mathrm{I})-\mathrm{Ni}(\mathrm{II})-\mathrm{P} 123$ and $\mathrm{Li}(\mathrm{I})-\mathrm{Co}(\mathrm{II})-\mathrm{P} 123$ clear solutions are stable indefinitely (no precipitation), but the $\mathrm{Mn}$ (II) and $\mathrm{Fe}$ (II) solutions require some attention and need to be immediately coated and converted into the lithium metal phosphates (LMPs) using freshly prepared solutions. The 
homogenization to obtain clear solutions may require additional time, during this period in the $\mathrm{Mn}$ (II) system, there is a small amount of precipitation (less than $1 \%$ of the initial precursors). However, the filtered solutions are stable and remain clear in all metal systems, investigated in this work. Note also that the solutions are highly acidic, typically in the $\mathrm{pH}$ range of 1.08 to 1.64 depending on the PA concentrations in the solutions, and also that the precipitation of some metal phosphate, such as in the Mn(II) solution, further acidifies those solutions, therefore the $\mathrm{Mn}$ (II) solutions are slightly more acidic. This is important for the growth and assembly of the growing LMP particles into mesostructures.

Adding the salts (both lithium and transition metal salts) to the PA-P123 mesophase also enhanced the meso-order; the fresh Li(I)-M(II)-PA-P123 mesophases with a very high ingredients/P123 mole ratios (up to 90:90:90:1 Li(I):M(II):PA:P123) also broadly diffract 2 lines at small angles in the 1.5 to $4^{\circ}(2 \theta)$ region, see Figure 2. However, the Li(I)-M(II)-PA-P123 LLC mesophases are not stable to aging, even at room temperature (RT) and/or mild heat treatments (see the inset in Figure 2), the meso-order is partially lost. The diffraction lines lose intensity and disappear upon aging and/or heating at around $50^{\circ} \mathrm{C}$, see Figure 2.

The $\mathrm{LiNO}_{3}-\mathrm{Fe}\left(\mathrm{NO}_{3}\right)_{3} \cdot 9 \mathrm{H}_{2} \mathrm{O}-\mathrm{PA}-\mathrm{P} 123$ solutions are not stable due to the $\mathrm{Fe}$ (III) that slowly undergoes hydrolysis and condensation reactions to form $\mathrm{FeO}(\mathrm{OH})$ species in the solution. To prevent this, we used $\left[\mathrm{Fe}\left(\mathrm{H}_{2} \mathrm{O}\right)_{6}\right] \mathrm{Cl}_{2}$ as the iron source, but the presence of the nitrate from the $\mathrm{LiNO}_{3}$ also results in the formation of $\mathrm{Fe}(\mathrm{III})$ species. Therefore, the lithium source was also changed to $\mathrm{LiCl}$ to form stable mesophases with $\mathrm{P} 123 .{ }^{[40]}$ The solutions of $\mathrm{LiCl}-\mathrm{FeCl}_{2}-\mathrm{PA}-\mathrm{P} 123$ are stable for an extended period (days to months). However, coating over a substrate cause slow oxidation of the $\mathrm{Fe}(\mathrm{II})$ to $\mathrm{Fe}(\mathrm{III})$, which can be

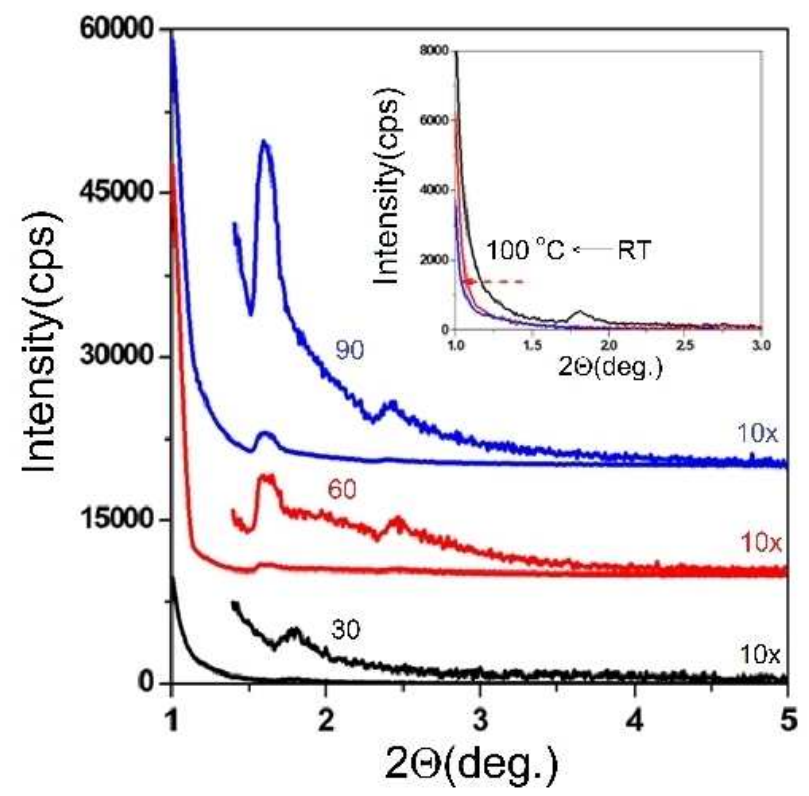

Figure 2. XRD patterns of $\mathrm{Li}(\mathrm{I}): \mathrm{Ni}(\mathrm{II}): \mathrm{PA}: \mathrm{P} 123$ with mole ratios of $30: 30: 30: 1,60: 60: 60: 1$, and $90: 90: 90: 1$. Inset is same as $30: 30: 30: 1$ mole ratio of $\mathrm{Li}(\mathrm{I}): \mathrm{Ni}(\mathrm{II}): \mathrm{PA}: \mathrm{P} 123$ heated from $\mathrm{RT}$ to $100^{\circ} \mathrm{C}$. observed by the change of the colour in the drop-cast coated film, from colourless to brick-red. The drop-cast coated Li(I)-Fe (II)-PA-P123 mesophases must be quickly calcined to prevent the formation of $\mathrm{Fe}_{2} \mathrm{O}_{3}$. Therefore, the $\mathrm{Mn}$ (II) and $\mathrm{Fe}(\mathrm{II})$ systems needs more investigation, both in the solution and gel phases.

\section{Synthesis and Characterization of Mesoporous LMPs}

By aging the drop-cast coated samples at room temperature or at higher temperatures, amorphous mesostructured LMP particles form and further heating to $300^{\circ} \mathrm{C}$ produces amorphous mesoporous LMPs. The synthesis of LMPs has been carried out in all composition (10 to 90 mole ratios, keeping the $\mathrm{Li}(\mathrm{I}): \mathrm{M}$ (II):PA mole ratio of $1: 1: 1)$ using $\mathrm{Li}(\mathrm{I})-\mathrm{Mn}(\mathrm{II})-\mathrm{PA}-\mathrm{P} 123 \mathrm{LLC}$ mesophases. The samples were prepared using either drop-cast coating or spin coating methods. The spin coated samples were used for TEM analysis and the drop-cast coated samples were used to collect the XRD patterns, $\mathrm{N}_{2}$ adsorption-desorption isotherms, and temperature dependent crystallinity and porosity related data.

The coated gel samples slowly undergo a polymerization reaction to form LMPs at as low as RT. Figure 3 shows a set of ATR-FTIR spectra of $60 \mathrm{Li}(\mathrm{I})-60 \mathrm{Ni}(\mathrm{II})-60 \mathrm{PA}-\mathrm{P} 123$ upon aging at RT over time and elevated temperatures. The peaks related to water, nitrate, and PA lose their intensity during RT aging, indicating the formation of metal phosphate and the removal of the nitrate as nitric acid or nitric oxides from the media, see Figure 3a. The ATR-FTIR spectrum of the Li(I)-Ni(II)-PA-P123 further changes upon heating to $50^{\circ} \mathrm{C}$, Figure $3 \mathrm{~b}$. The peaks corresponding to PA slowly disappear and metal phosphate related peaks appear over time, see Figure 3 . The nitrate peaks completely disappear from the spectra at $250^{\circ} \mathrm{C}$ and the spectra of the samples do not change at higher temperatures up to the crystallization temperature, compare spectra in Figure $3 \mathrm{~b}$. Similar spectral changes were also observed in all other LMP systems; therefore, they are not included in the text.

The quantity of inorganic ingredients $(\mathrm{Li}(\mathrm{I})$ and $M(\mathrm{II})$ salts and $\mathrm{PA}$ ) and the temperature of aging/calcination determine the morphology of the LMP particles, see Figure 4. These samples were abbreviated as DLMP\# (where D stands for dropcast coated, L, M, and P stands for lithium, transition metal, and phosphate and the \# is the PA/P123 mole ratio). Figure 4 shows
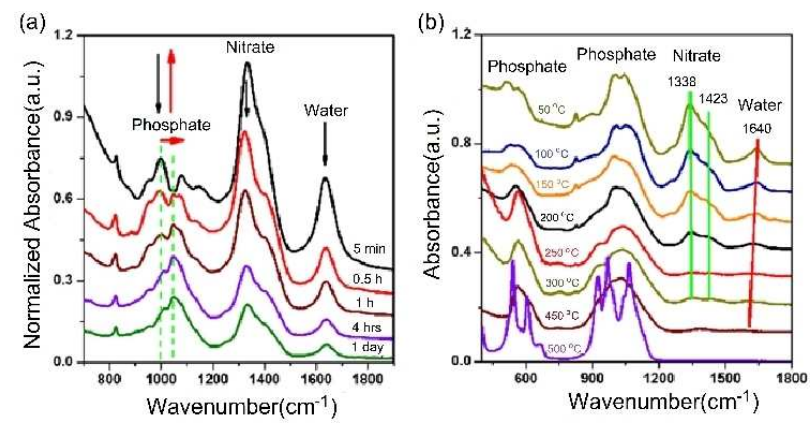

Figure 3. ATR-FTIR spectra of Li(I)-Ni(II)-PA-P123 at (a) RT over time and (b) with increasing temperatures. 

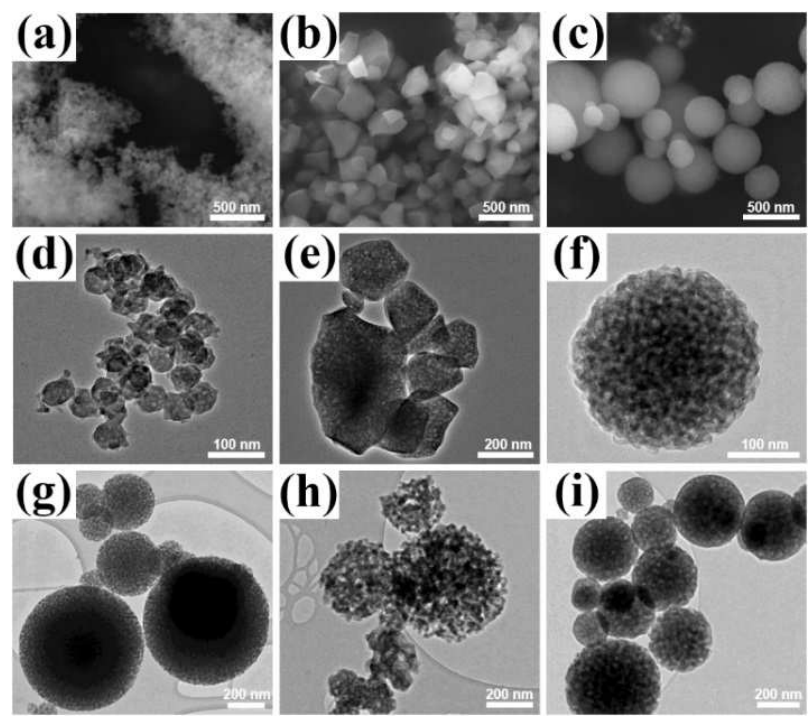

Figure 4. SEM (a-c) and TEM (d-f) images of $\mathrm{LiCOPO}_{4}$, obtained from DLCoP10, DLCoP40, and DLCoP90 and TEM images of $(\mathrm{g}) \mathrm{LiNiPO}_{4}(\mathrm{~h})$ $\mathrm{LiMnPO}_{4}$, and (i) $\mathrm{LiCoPO}_{4}$.

a set of representative SEM and TEM images of the samples, obtained from DLCoP10, DLCoP40, and DLCoP90 and DLNiP60, DLMnP60, and DLCoP60, calcined at $300^{\circ} \mathrm{C}$. The particles are uniform with a crystal-like morphology, obtained from the low ingredient (10 to 40 ) or high P123 concentrations and low temperatures (RT to $100^{\circ} \mathrm{C}$ ), but they are spherical at higher ingredient (40 to 90) concentrations and high temperatures (above $100^{\circ} \mathrm{C}$ ). Both the SEM and TEM images confirm the formation of uniform spherical particles with large pores and pore-walls. Note also that the amorphous samples are beam sensitive and undergo crystallization during HRTEM imaging, see Figure S1 (Supporting Information).

In general, the particles are big (typically $<100 \mathrm{~nm}$ ) in low and small $(>50 \mathrm{~nm}$ ) in the high P123 concentrations, likely due to enhanced seeding step with increasing the ingredients concentrations in the LLC media. Both $\mathrm{LiMnPO}_{4}$ and $\mathrm{LiCoPO}_{4}$ samples were prepared over a broad range of transition metal ion (M(II)) concentrations, from 10 to $90 \mathrm{M}(\mathrm{II}) / \mathrm{P} 123$ mole ratio by an increment of $10 \mathrm{M}$ (II) per P123 to show how the mesophases are flexible to the ingredient concentrations, see Figure S2. However, 3 concentrations $(30$ as low, 60 as intermediate, and 90 as high $\mathrm{Mn}(\mathrm{II}) / \mathrm{P} 123$ mole ratio) were chosen to investigate and to optimize the synthesis conditions for all LMPs. Note also that the shape of the particles, obtained from these 3 compositions, are very similar in all LMPs.

The $\mathrm{N}_{2}$ adsorption-desorption isotherms of all LMPs display type IV isotherms, characteristic of the mesoporous materials and consistent with the images, see Figures $5 \mathrm{a}$ and S2. All DLMP30, DLMP60, and DLMP90 particles are amorphous and spherical up to $400^{\circ} \mathrm{C}$. However, the surface area of DLMP60 is the largest of all samples, therefore most data were collected using the calcined DLMP60 samples. The Brunauer-EmmettTeller (BET) surface area of LMPs, calcined at $300^{\circ} \mathrm{C}$, vary between 19 and $79 \mathrm{~m}^{2} / \mathrm{g}$, depending on the transition metal
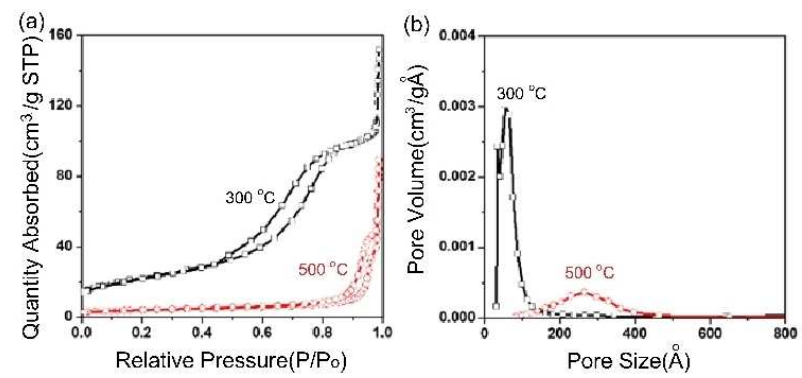

Figure 5. (a) $\mathrm{N}_{2}$ adsorption-desorption isotherms of DNi60-300 and DNi60500 and (b) their BJH pore-size distribution plots.

\begin{tabular}{|c|c|c|c|}
\hline Samples & $\begin{array}{l}\mathrm{SA} \\
{\left[\mathrm{m}^{2} / \mathrm{g}\right]}\end{array}$ & $\begin{array}{l}\text { PS } \\
{[\mathrm{nm}]}\end{array}$ & $\begin{array}{l}\text { PV } \\
{\left[\mathrm{cm}^{3} / \mathrm{g}\right]}\end{array}$ \\
\hline DLCoP60-300 & 23 & 14.8 & 0.124 \\
\hline DLCoP60-500 & 5 & 28.1 & 0.008 \\
\hline DLFeP60-300 & 19 & 14.2 & 0.072 \\
\hline DLFeP60-500 & 7 & 36.7 & 0.059 \\
\hline DLMnP60-300 & 35 & 30.4 & 0.243 \\
\hline DLMnP60-500 & 2 & 26.5 & 0.009 \\
\hline DLNiP60-300 & 79 & 8.9 & 0.236 \\
\hline DLNiP60-500 & 14 & 42.6 & 0.137 \\
\hline
\end{tabular}

and inorganic ingredient concentration in the mesophase. The largest surface area was observed in the $\mathrm{Ni}(\mathrm{II})$ samples with a surface area of $79 \mathrm{~m}^{2} / \mathrm{g}$, a Barret-Joyner-Halenda (BJH) pore size of $8.9 \mathrm{~nm}$, and pore-wall thickness of about $15 \mathrm{~nm}$, Table 1. The BET surface areas are 35 and $23 \mathrm{~m}^{2} / \mathrm{g}$ for the mesoporous $\mathrm{LiMnPO}_{4}$ and $\mathrm{LiCoPO}_{4}$ samples, and $19 \mathrm{~m}^{2} / \mathrm{g}$ in $\mathrm{Li}_{3} \mathrm{Fe}_{2}\left(\mathrm{PO}_{4}\right)_{3 \prime}$ respectively, calcined at $300^{\circ} \mathrm{C}$. The lowest surface area was observed in the iron samples, likely due to the presence of some bulk $\mathrm{Fe}_{2} \mathrm{O}_{3}$, see latter. Further annealing of the samples at $500^{\circ} \mathrm{C}$ reduces the surface area from 79 to 14,35 to 2,23 to 5 , and 19 to $7 \mathrm{~m}^{2} / \mathrm{g}$ in the $\mathrm{LiNiPO}_{4}, \mathrm{LiMnPO}_{4}, \mathrm{LiCoPO}_{4}$ and iron compound, respectively, indicating a large increase in the poresize and pore-wall thickness. The expansion of the pore-size to 25-30 nm and crystallization of the pore-walls were observed in all LMPs, see Figures $5 b$ and S3. The line shape of the isotherms reflects these changes in the pore system as observed in mesoporous calcium hydroxyapatite, prepared using a similar method. ${ }^{[15]}$

The crystallization of the pore-walls has also been shown using XRD and TEM imaging techniques. Figures 6 and 7 show sets of XRD patterns, obtained from the DLMP60 of Ni(II), Mn(II), and $\mathrm{Co}(\mathrm{II})$. Clearly, all LMPs are amorphous up to $400^{\circ} \mathrm{C}$ and become highly crystalline above $500^{\circ} \mathrm{C}$. We also noticed a profound difference between direct heating of the drop cast coated samples over glass substrates to $500^{\circ} \mathrm{C}$ and $300^{\circ} \mathrm{C}$ calcination over a glass slide, followed by annealing at $500^{\circ} \mathrm{C}$ in an alumina sample holder. The second method produced the LMPs but the first method produced an Na version, NaMPs with a maricite structure. An ion exchange reaction occurs between the LMPs and glass substrates (the exchange behaviour will be 


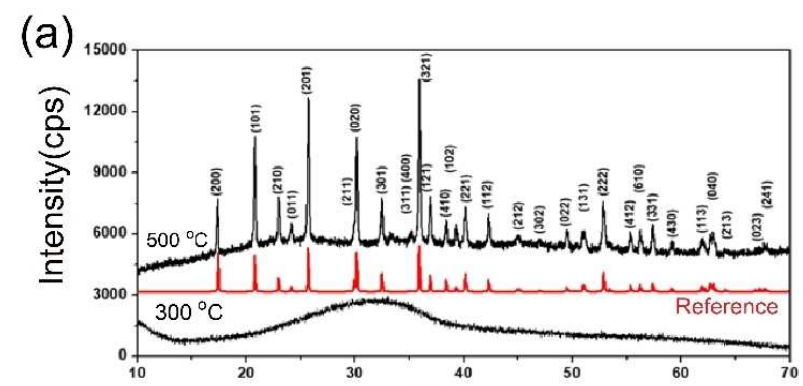

(b)

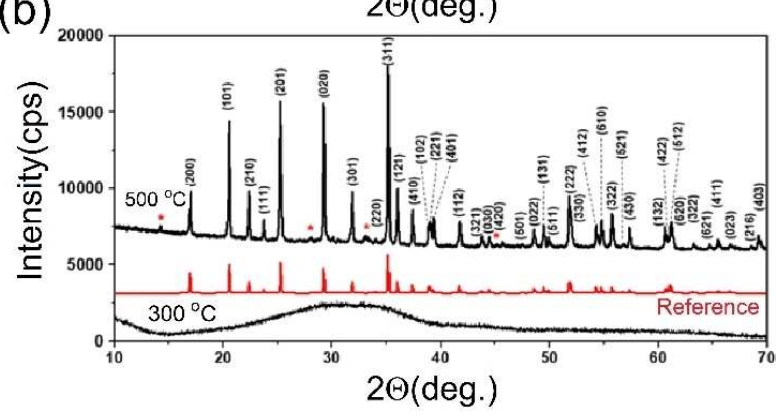

Figure 6. PXRD patterns of calcined (a) $\mathrm{LiCoPO}_{4}$ and (b) $\mathrm{LiMnPO}_{4}$ at $300^{\circ} \mathrm{C}$ (bottom) and annealed to $500^{\circ} \mathrm{C}$ (top) and middle ones are reference data.
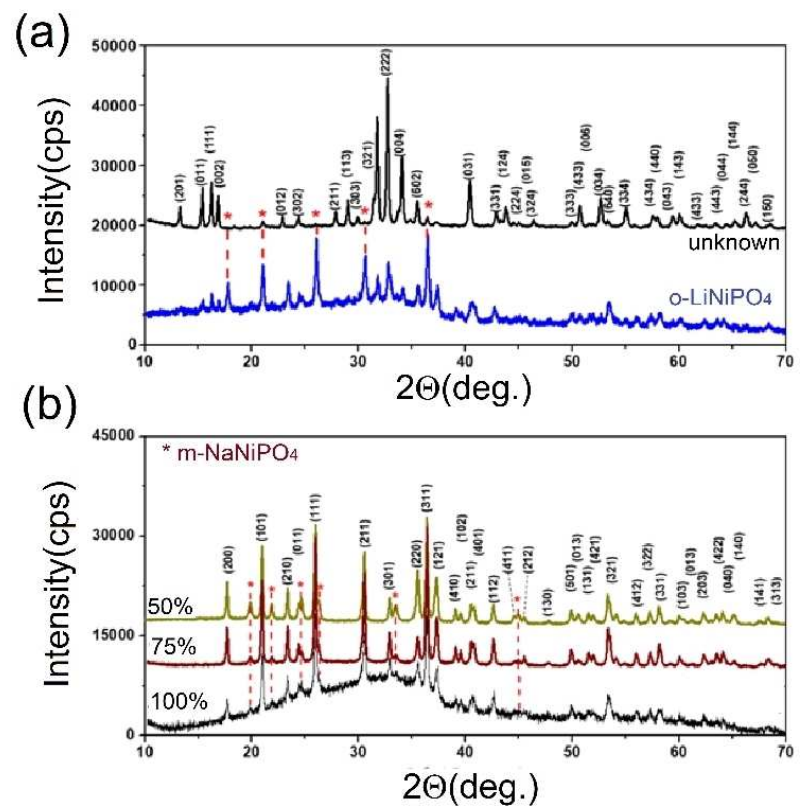

Figure 7. PXRD patterns of $\mathrm{LiNiPO}_{4}$, prepared using (a) 0 and $25 \%$ and (b) 50 , 75 , and $100 \% \mathrm{LiH}_{2} \mathrm{PO}_{4}$ (top to bottom) as lithium and phosphate source at $500^{\circ} \mathrm{C}$.

discussed elsewhere, and not be included in this work to mainly focus on LMPs).

The DLCoP60 and DLMnP60 display diffraction lines that can be indexed to an olivine phase (orthorhombic, Pnba space group), denoted as $\mathrm{o}-\mathrm{LiMnPO}_{4}$ and $\mathrm{o}-\mathrm{LiCoPO}$, see Figure 6. The unit cell parameters, evaluated from the patterns, are consistent with the PDF cards and listed in Table 2. The DLFeP60 and DLNiP60 also produce amorphous compounds at $300^{\circ} \mathrm{C}$, but they crystallize over $500^{\circ} \mathrm{C}$ to a mixture of a few crystalline

\begin{tabular}{|c|c|c|c|c|}
\hline Materials & $\mathrm{a}[\AA ̊]$ & $\mathrm{b}[\AA \AA]$ & $c[\AA ̊]$ & $V\left[\AA^{3}\right]$ \\
\hline o-LiMnPO ${ }_{4}^{[a]}$ & 10.435 & 6.096 & 4.735 & 301.2 \\
\hline $0-\mathrm{LiCoPO}_{4}^{[\mathrm{a}]}$ & 10.202 & 5.923 & 4.703 & 284.2 \\
\hline $0-\mathrm{LiNiPO}_{4}^{\left[{ }^{\text {a] }}\right.}$ & 10.033 & 5.854 & 4.678 & 274.7 \\
\hline $\mathrm{FePO}_{4}{ }^{[\mathrm{b}]}$ & 5.035 & 5.035 & 11.245 & 246.9 \\
\hline $\mathrm{Li}_{3} \mathrm{Fe}_{2}\left(\mathrm{PO}_{4}\right)_{3}{ }^{[\mathrm{c}]}$ & 8.571 & 12.017 & 8.616 & 887.4 \\
\hline
\end{tabular}

metal phosphate phases. Interestingly, all metals formed an olivine structure of LMPs, except $\mathrm{Ni}(\mathrm{II})$, which produces a nickel deficient metal phosphate under a similar reaction condition. The reaction conditions are slightly modified by increasing the amount of $\mathrm{Li}(\mathrm{l})$ in the initial solution by 10 to $20 \mathrm{~mol} \%$ to produce an olivine rich mixture. However, the synthesis condition must be set properly. In the excess $\mathrm{LiNO}_{3}$ cases, the calcination at low temperature and annealing to $500^{\circ} \mathrm{C}$ produces $\mathrm{o}$ - $\mathrm{LiNiPO}_{4}$ with another crystalline unknown phase. However direct calcination, over glass substrate, at $500^{\circ} \mathrm{C}$ even with excess lithium produces the unknown phase, see Figure $\mathrm{S} 4$ and Table 2. The formation of the olivine phase can also be enhanced by adjusting the $\mathrm{pH}$ of the initial solution. To increase the $\mathrm{pH}$ of the solution, we systematically added $\mathrm{LiH}_{2} \mathrm{PO}_{4}$ in place of both $\mathrm{PA}$ and $\mathrm{LiNO}_{3}$ as the phosphate and $\mathrm{Li}(\mathrm{I})$ source in the initial solutions.

Figure 7 shows the changes in the XRD patterns of the LNiP samples, calcined at $300^{\circ} \mathrm{C}$ and then annealed at $500^{\circ} \mathrm{C}$; the samples were prepared using the solutions with an increasing $\mathrm{LiH}_{2} \mathrm{PO}_{4} / \mathrm{PA}$ ratio of the initial solution. Clearly, if the lithium and phosphate sources are $\mathrm{LiNO}_{3}$ and $\mathrm{PA}$, the unknown phase forms at $500^{\circ} \mathrm{C}$. However, replacing the $\mathrm{LiNO}_{3}$ and PA with a $25 \mathrm{~mol} \%$ $\mathrm{LiH}_{2} \mathrm{PO}_{4}$ source produces a mixture of $\mathrm{O}-\mathrm{LiNiPO}_{4}$ and the unknown phases, see Figure 7a. Further increase of the $\mathrm{LiH}_{2} \mathrm{PO}_{4}$ amount in the initial solution to a $50 \% \mathrm{LiH}_{2} \mathrm{PO}_{4}(50 \%$ of $\mathrm{Li}(\mathrm{I})$ and $\mathrm{PO}_{4}{ }^{3-}$ source is $\mathrm{LiH}_{2} \mathrm{PO}_{4}$ and the other $50 \%$ is from $\mathrm{LiNO}_{3}$ and $\mathrm{PA}$ ) and to a $75 \% \mathrm{LiH}_{2} \mathrm{PO}_{4}$ produce a mixture with much of the olivine phase.

In addition to the $\mathrm{o}-\mathrm{LiNiPO}_{4}$ (orthorhombic, unit cell parameters of $a=10.032(7) \AA, b=5.853(9) \AA, c=4.677(8) \AA$ and a unit cell volume of $\left.274.7 \AA^{3}\right)$ phase, a maricite $\mathrm{NaNiPO}_{4}(\mathrm{~m}$ $\mathrm{NaNiPO}_{4}$, orthorhombic, unit cell parameters of $a=6.123(5) \AA$, $b=8.935(8) \AA \AA \quad c=4.560(0) \AA$, and $V=249.5 \AA^{3}$ ) phase also forms. ${ }^{[43-45]}$ We found that the further calcination of the dropcast coated samples undergo an ion-change reaction over the glass slides at higher temperatures. Over $300^{\circ} \mathrm{C}$ the ionexchange of $\mathrm{Na}(\mathrm{I})$ of glass and $\mathrm{Li}(\mathrm{I})$ of the samples begins and completes at around $500^{\circ} \mathrm{C}$. Therefore, the further annealing processes must be carried by collecting the samples from the glass surface and annealing in alumina sample holders. This ensures crystalline $O$-LMPs. Otherwise, the direct synthesis over glass slides at $500^{\circ} \mathrm{C}$ or calcination at $300^{\circ} \mathrm{C}$ followed by $500^{\circ} \mathrm{C}$ annealing over glass slides produces the maricite NaMP $(m-$ NaMP) phases. ${ }^{[46,47]}$ The $m$-NaMP formation will be discussed elsewhere. This article focuses on the synthesis of the mesoporous olivine phase of LMPs. 


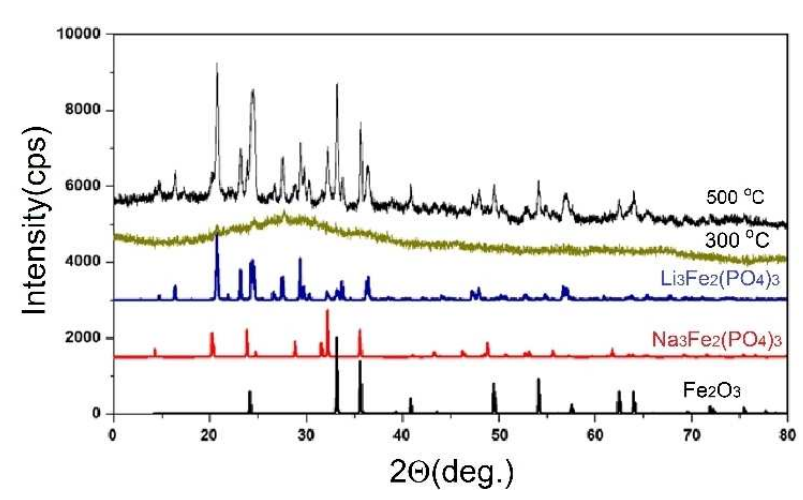

Figure 8. PXRD pattern of DLFeP60, calcined at (a) $300^{\circ} \mathrm{C}$ and (b) $500^{\circ} \mathrm{C}$, with PDF data of $\mathrm{Fe}_{2} \mathrm{O}_{3}, \mathrm{Li}_{3} \mathrm{Fe}_{2}\left(\mathrm{PO}_{4}\right)_{3}$, and $\mathrm{Na}_{3} \mathrm{Fe}_{2}\left(\mathrm{PO}_{4}\right)_{3}$.

Since the LFeP system behaved differently than the other LMPs, we also investigated the lithium iron phosphate (LFeP) system using two different iron sources, namely $\mathrm{Fe}\left(\mathrm{NO}_{3}\right)_{3} \cdot 9 \mathrm{H}_{2} \mathrm{O}$ and $\mathrm{FeCl}_{2} \cdot 6 \mathrm{H}_{2} \mathrm{O}$ salts. Figure 8 shows the XRD pattern of the calcination products that were identified as a mixture of $\mathrm{Fe}_{2} \mathrm{O}_{3}$, orthorhombic and monoclinic $\mathrm{Li}_{3} \mathrm{Fe}_{2}\left(\mathrm{PO}_{4}\right)_{3}$ and $\mathrm{Na}_{3} \mathrm{Fe}_{2}\left(\mathrm{PO}_{4}\right)_{3}$, respectively, depending on the ingredients and $\mathrm{pH}$ of the initial solutions. The stoichiometric ingredient concentrations $(1: 1: 1$, $\mathrm{Li}: \mathrm{Fe}: \mathrm{PA}$ for $\mathrm{LiFePO}_{4}$ ) produced various $\mathrm{Fe}(\mathrm{III})$ compounds. Although, the iron ion in solution phases are stabilized as $2+$ (in case of $\mathrm{FeCl}_{2}$ ) and $3+$ (in case of $\mathrm{Fe}\left(\mathrm{NO}_{3}\right)_{3}$ ) by adding excess acid to the solutions, the calcination in the oven produced $\mathrm{Fe}$ (III) compounds. Since the products are predominantly Fe(III), we changed the stoichiometry in the solution phase as $3: 2: 3$ $(\mathrm{Li}(\mathrm{I}): \mathrm{Fe}(\mathrm{III})$ (or $\mathrm{Fe}(\mathrm{II})): \mathrm{PA}$ ) to produce pure phase of the $\mathrm{Li}_{3} \mathrm{Fe}_{2}\left(\mathrm{PO}_{4}\right)_{3}$ phase and to $1: 1(\mathrm{Fe}(\mathrm{III}): \mathrm{PA})$ to produce the $\mathrm{FePO}_{4}$. If the $\mathrm{Fe}\left(\mathrm{NO}_{3}\right)_{3}$ was used as an iron source, the calcination of the gel phase produced a pure $\mathrm{Li}_{3} \mathrm{Fe}_{2}\left(\mathrm{PO}_{4}\right)_{3}$ but the $\mathrm{FeCl}$ also produced the same compound with a small amount of $\mathrm{Fe}_{2} \mathrm{O}_{3}$ impurity.

We also employed the $\mathrm{LiH}_{2} \mathrm{PO}_{4}$ as the lithium and phosphate source. However, the solution phase was not stable and $\mathrm{FePO}_{4} \cdot 2 \mathrm{H}_{2} \mathrm{O}$ crystallites precipitated at room temperature, see Figure $\mathrm{S} 5 \mathrm{a}$. Notice that the $\mathrm{pH}$ of this solution is above 3.5 and adding excess $\mathrm{HCl}$ (decreasing the $\mathrm{pH}$ ) stabilized the solution phase (no precipitation) and produced the same products. We also prepared the gel phase and calcination product of iron nitrate, PA, and P123 mixture (without a lithium source) to obtain $\mathrm{FePO}_{4}$. Figure $\mathrm{S} 5 \mathrm{~b}$ shows the XRD pattern of the calcination product, $\mathrm{FePO}_{4}$ powder with some undefined phase (marked with ${ }^{*}$ in the pattern). The unit cell parameters of $\mathrm{FePO}_{4}$ were evaluated to be $a=b=5.034 \AA, c=11.245 \AA, V=$ $246.85 \AA^{3}$, and a space group of P321. The product has a mixture of two morphologies, spherical and film particles, see Figure S6. Further investigation is needed to elucidate the undefined phases in the LFePs and $\mathrm{FePO}_{4}$.

Both the amorphous and crystalline phases of the above materials were further investigated using ATR-FTIR spectroscopy. The amorphous phases display broad features in the phosphate stretching $\left(900-1200 \mathrm{~cm}^{-1}\right)$ and bending regions $\left(450-650 \mathrm{~cm}^{-1}\right)$, see Figure 9. The origin of broadening is due to
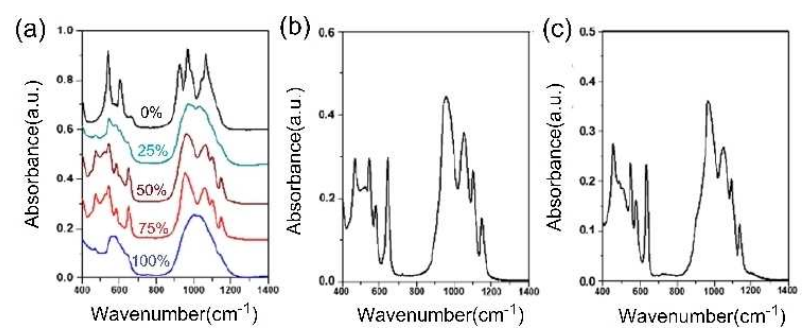

Figure 9. ATR-FTIR spectra of (a) a set of $\mathrm{LiNiPO}_{4}$ prepared using 0 to $100 \%$ of $\mathrm{LiH}_{2} \mathrm{PO}_{4}$ (top to bottom), (b) o-LiCoPO , and (c) o-LiMnPO 4 .

presence of defects and the breaking of the periodicity of the lattice sides in the amorphous LMPs. ${ }^{[48]}$ However, the crystalline samples have characteristic peaks of the olivine phases in all LMPs, Figure 9b-c. Spectra of the olivine LMPs display very similar features and can be used to identify the olivine phases. The sharp peaks at 1138, 1092, 1049 (due to antisymmetric stretching modes), $967 \mathrm{~cm}^{-1}$ (symmetric stretching mode) and peaks at $634,577,548,509,488,454 \mathrm{~cm}^{-1}$ (due to bending modes of the phosphate units and $\mathrm{Li}-\mathrm{O}$ and $\mathrm{Mn}-\mathrm{O}$ stretching modes) are observed in the 0 - $\mathrm{LiMnPO}_{4}$. These features are slightly blue shifted and observed at 1150, 1101, 1052, 958, 643, $578,545,522$, and $467 \mathrm{~cm}^{-1}$ in the $0-\mathrm{LiCoPO}_{4}$.

Increasing the lithium salt amount by 10 to $20 \mathrm{~mol} \%$ (after the calcination at $300^{\circ} \mathrm{C}$ and then annealing at $500^{\circ} \mathrm{C}$ ) produces the $\mathrm{o}-\mathrm{LiNiPO}_{4}$ phase but direct calcination at $500^{\circ} \mathrm{C}$ produces the unknown phase. ATR-FTIR spectra of these samples are given in Figure S7. Clearly, the spectral changes correlate with the XRD results (Figures 9 and S7). The spectral changes, with increasing $\mathrm{LiH}_{2} \mathrm{PO}_{4}$ in the initial solution, were also monitored using the ATR-FTIR spectroscopy. With a replacement of $25 \%$ of $\mathrm{LiNO}_{3}$ and PA with $\mathrm{LiH}_{2} \mathrm{PO}_{4}$, new peaks emerge (in the ATR-FTIR spectra) at 1147 (sharp), 1098 (sharp), $1058 \mathrm{~cm}^{-1}$ (broad) due antisymmetric stretching modes and a broad peak at $958 \mathrm{~cm}^{-1}$ due to symmetric stretching mode of the phosphate units of the $o$-LiNiPO 4 phase. The peaks at $661,647,580,542,520$, and $470 \mathrm{~cm}^{-1}$ belong to the bending modes of phosphate units and the stretching modes of the $\mathrm{Li}-\mathrm{O}$ and $\mathrm{Ni}-\mathrm{O}$ bonds. These features gradually dominate the spectra with an increasing $\mathrm{LiH}_{2} \mathrm{PO}_{4}$ ratio in the synthesis solution, see Figure 9a. The broad spectra are observed in both 25 and $100 \% \mathrm{LiH}_{2} \mathrm{PO}_{4}$ cases, due to presence of the amorphous phases in the samples. The spectral features and changes accord well with the changes in the XRD patterns. Simply, the olivine phase dominates in the spectra with an increasing $\mathrm{LiH}_{2} \mathrm{PO}_{4}$ precursor in the synthesis. The shape of the LNiP particles also change with increasing $\mathrm{LiH}_{2} \mathrm{PO}_{4}$, as shown in the SEM images, see Figure S8.

To further analyse the LMPs, K-edge X-ray absorption near edge structure (XANES) data were also collected in the SESAME (Jordon) synchrotron facility. Figure 10 shows a series of K-edge XANES spectra of the LMPs. The XANES spectra display weak pre-edge peaks on the low energy side of $E_{0}$, due to a $1 \mathrm{~s} \rightarrow 3 \mathrm{~d}$ transition, a strong $1 s \rightarrow 4 p$ transition on the K-edge, and a peak at high energy of the edge due to a $1 \mathrm{~s} \rightarrow$ continuum transition. ${ }^{[49]}$ 
(a)

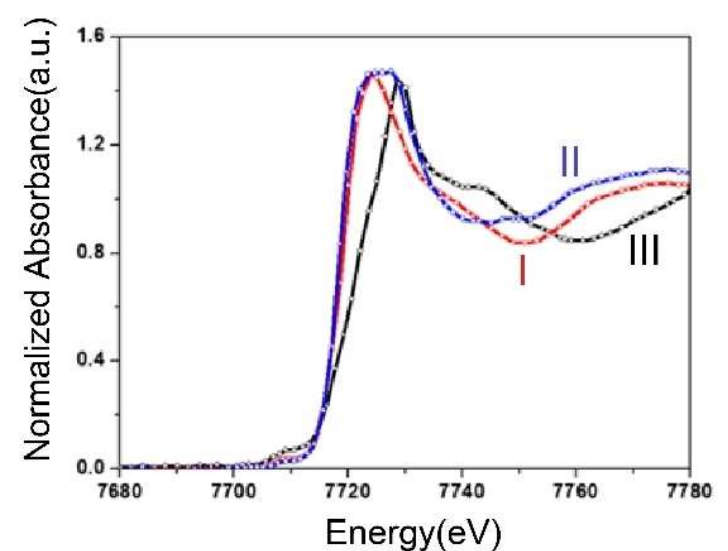

(b)

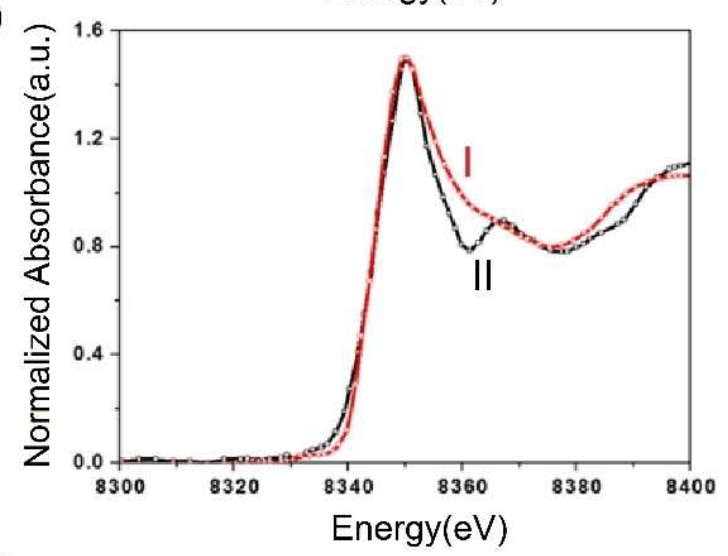

(c)

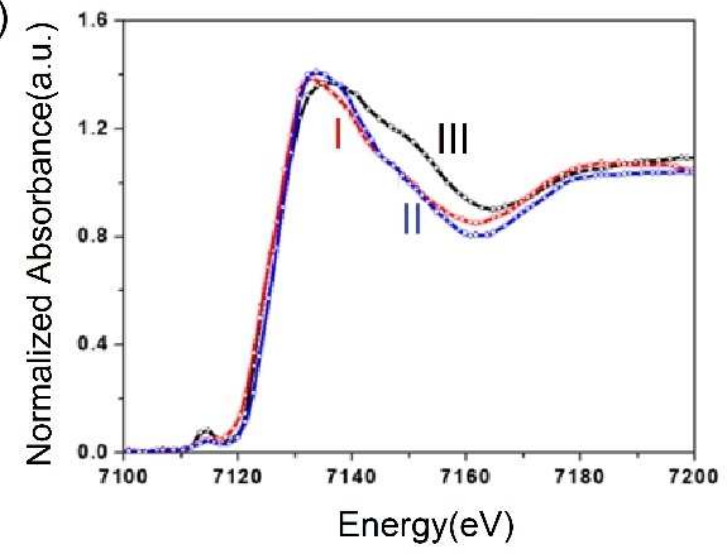

Figure 10. K-edge XANES spectra of LMPs: (a) I) $300^{\circ} \mathrm{C}$ and II) $500^{\circ} \mathrm{C}$ of LCoP and III) $\mathrm{CO}_{3} \mathrm{O}_{4}$, (b) I) $\mathrm{LNiP}$ and II) $\mathrm{NiO}$, and (c) I) $200^{\circ} \mathrm{C}$ and II) $500^{\circ} \mathrm{C} \mathrm{LFeP}$ and III) $\mathrm{FePO}_{4}$.

The XANES spectra of $\mathrm{LiCOPO}_{4}$ samples display a weak preedge signal at around $7710 \mathrm{eV}$ due to a $1 \mathrm{~s} \rightarrow 3 \mathrm{~d}$, a strong $1 \mathrm{~s} \rightarrow$ $4 \mathrm{p}$ transition on the K-edge, and a $1 \mathrm{~s} \rightarrow$ continuum transition at around $7724 \mathrm{eV}$, all characteristic for the $\mathrm{Co}^{2+}$ oxidation state. ${ }^{[49]}$ The XANES spectrum of $\mathrm{Co}_{3} \mathrm{O}_{4}$ is also given in Figure 10a to compare the oxidation state of cobalt in the $\mathrm{LiCoPO}_{4}$. Notice that in $\mathrm{Co}_{3} \mathrm{O}_{4}$, the $\mathrm{Co}^{2+}$ and $\mathrm{Co}^{3+}$ co-exist and the $1 \mathrm{~s} \rightarrow$ continuum transition is observed at $7729 \mathrm{eV}$. The olivine structure, calcined at $300^{\circ} \mathrm{C}$ and $700^{\circ} \mathrm{C}$ displays a sharp peak at around $7724 \mathrm{eV}$, see Figure 10a.
Figure $10 \mathrm{~b}$ shows the Ni K-edge XANES spectra of $\mathrm{LiNiPO}_{4}$ and $\mathrm{NiO}$. The other phases of LNiPs also display a very similar XANES features, indicating that the $\mathrm{Ni}$ is in $2+$ oxidation states in all LNiPs, investigated in this work. Figure 10c shows 3 spectra in the Fe K-edge region, collected from LFePs. Notice that the pre-edge line is observed at around $7114 \mathrm{eV}$ due to $1 \mathrm{~s} \rightarrow 3 \mathrm{~d}$ transition. However, the $\mathrm{Fe}^{2+}$ species display two peaks in this region at around $7112 \mathrm{eV}$ due to $1 \mathrm{~s} \rightarrow 3 \mathrm{~d}\left(\mathrm{t}_{2 \mathrm{~g}}\right.$ and $\mathrm{e}_{\mathrm{g}}$ levels) transition but the $\mathrm{Fe}^{3+}$ species display one peak at $7114 \mathrm{eV}$. Also, the $1 \mathrm{~s} \rightarrow$ continium transition is observed above $7132 \mathrm{eV}$ in the iron phosphates. The sample that contains $\mathrm{Li}(\mathrm{I})$, heated at 200 and $500^{\circ} \mathrm{C}$, displays relatively sharper peaks at around $7132 \mathrm{eV}$, but $\mathrm{FePO}_{4}$ display two broad features at 7137 and $7148 \mathrm{eV}$ region. A similar broad feature is observed after charging the $\mathrm{LiFePO}_{4}$ to $\mathrm{FePO}_{4}$, where the iron is in $3+$ oxidation state. The XANES data also show that it is difficult to keep iron in a $2+$ oxidation state even at $200^{\circ} \mathrm{C}$. If we start with $\mathrm{FeCl}_{2}$ as iron source, the iron in the product is in $3+$ oxidation state under our reaction conditions (likely due to air oxidation during the calcination process).

The electrochemical energy storage ability of LMPs were further investigated by making coin cells. The cells were charged/discharged on a constant current mode in the 2.0 to 5.0 $\mathrm{V}$ for LMPs (where $\mathrm{M}$ is $\mathrm{Co}, \mathrm{Mn}$, and $\mathrm{Fe}$ ) and 2.0 to $5.4 \mathrm{~V}$ for $\mathrm{LNiP}$ versus $\mathrm{Li} / \mathrm{Li}^{+}$using a $1 \mathrm{M} \mathrm{LiPF}_{6}$ in EC/DMC (3:7 v/v ratio) at a current density of $20 \mathrm{~mA} / \mathrm{g}$. The LMPs, calcined at $300^{\circ} \mathrm{C}$ showed a very low charge capacity likely due to their amorphous nature. However, the crystalline samples (calcined at 300 and annealed at $500^{\circ} \mathrm{C}$ ) of $\mathrm{o}-\mathrm{LiCoPO}_{4}$ and $\mathrm{LFeP}$ showed reasonable capacities. Figure 11 shows the related data for $o^{-}$

(a)

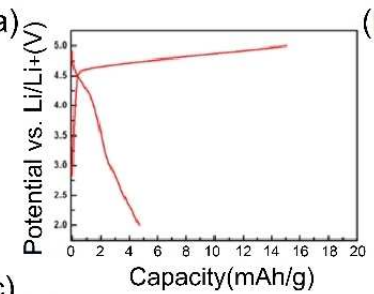

(c)
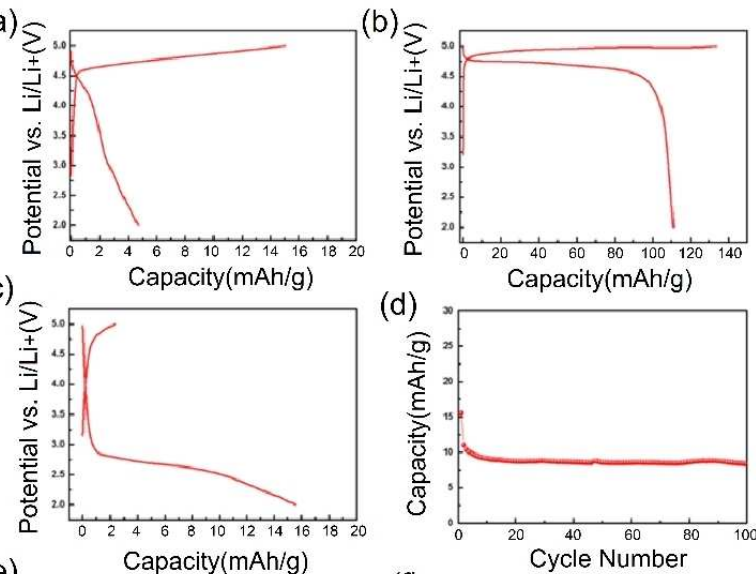

(d)

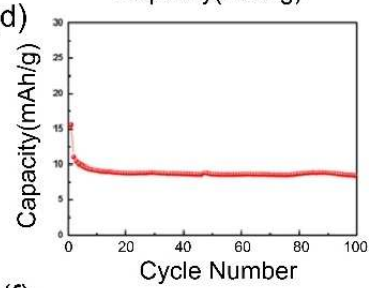

(e)
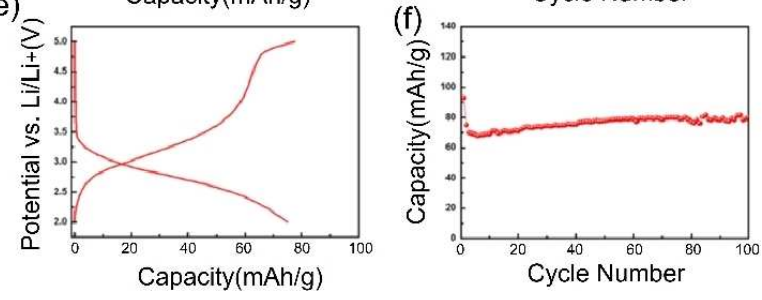

Figure 11. Electrochemical performances of lithium ion cells, charge-discharge curves (a-c, and e) and cycling performances ( $d$ and $f$ ). The chargedischarge curves of DLCoP60, calcined at (a) $300^{\circ} \mathrm{C}$ and (b) $500^{\circ} \mathrm{C}$ and of DLFeP60, calcined at (c) $300^{\circ} \mathrm{C}$ and (e) $500^{\circ} \mathrm{C}$ and their cycling performances (d and f), respectively. 
$\mathrm{LiCoPO}_{4}$ and $\mathrm{LFeP}$ samples. The Co sample showed a capacity of $110.9 \mathrm{mAh} / \mathrm{g}$ in the first cycle, but it decreased to a $14.5 \%$ capacity after 100 cycles. Even though the LFeP is not a pure phase (as detected in the XRD and ICP-MS data, a small amount of $\mathrm{Fe}_{2} \mathrm{O}_{3}$ and $\mathrm{Na}_{3} \mathrm{Fe}_{2}\left(\mathrm{PO}_{4}\right)_{2}$ exist in the samples, see XRD section of LFeP), it retained its $86.2 \%$ capacity of $93 \mathrm{mAh} / \mathrm{g}$ after 100 cycles. However, both LMnP and LiNiP samples showed no reaction with the lithium ion. To improve reactivity with lithium and cyclability of mesoporous $\mathrm{LiMPO}_{4}$, further electrochemical studies are required by further optimizing the synthesis conditions.

\section{Conclusion}

The PA-P123 and LiNO $-M(I I)-P A \_P 123$ (M(II) is Mn(II), Fe(II), Co (II), and $\mathrm{Ni}(\mathrm{II})$ and also $\mathrm{Fe}(\mathrm{III})$ ) form LLC mesophase in a very broad range of inorganic ingredient concentrations. The mesophase of PA-P123 is stable indefinitely in the presence of 2-3 water per PA in the media. The PA-P123 is highly ordered up to $30 \mathrm{PA} / \mathrm{P} 123$ and becomes disordered up to $100 \mathrm{PA} / \mathrm{P} 123$ mole ratios. Addition of the salts to the media enforces the meso-order up to $90 \mathrm{PA} / \mathrm{P} 123$, in the presence of $90 \mathrm{Li}(\mathrm{l})$ and $90 \mathrm{M}$ (II) per P123. However, the mixed ingredient mesophases are not stable and slowly undergo polymerization reaction to form MA-LMPs. All compositions produce MA-LMPs, with different morphologies and particle sizes up to $400^{\circ} \mathrm{C}$ and which have crystalline LMPs above $400^{\circ} \mathrm{C}$.

The LMPs of Co(II) and Mn(II) have an olivine structure upon calcining the drop-cast coated solutions to $300^{\circ} \mathrm{C}$ and then annealing to $500^{\circ} \mathrm{C}$. Direct calcination of the drop-cast coated samples, over glass substrates, undergo $\mathrm{Na}+$ ion exchange with the substrate at $500^{\circ} \mathrm{C}$ to produce a maricite phase (NaMPs). A similar procedure, in the case of $\mathrm{Ni}(\mathrm{II})$, produces an amorphous $\mathrm{LNiP}$ that undergoes ion exchange and produces $\mathrm{Na}_{4} \mathrm{Ni}_{3}\left(\mathrm{PO}_{4}\right)_{2} \mathrm{P}_{2} \mathrm{O}_{7}$ either by calcination at low temperature and then crystallization at higher temperatures or by directly calcining at high temperatures. However, increasing the $\mathrm{LiNO}_{3}$ amount by $10 \%$ or using $\mathrm{LiH}_{2} \mathrm{PO}_{4}$ as $\mathrm{Li}(\mathrm{I})$ and phosphate source (also higher $\mathrm{pH}$ ) produces the olivine phase of $\mathrm{LiNiPO}_{4}$. The LFeP system is the most complicated system. Even though the $\mathrm{Fe}$ (II) could be stabilized in the solution phase, the calcination of $\mathrm{Li}(\mathrm{I})-\mathrm{Fe}(\mathrm{II})-\mathrm{PA}-\mathrm{P} 123$ resulted a mixture of $\mathrm{Fe}(\mathrm{III})$ species, namely $\mathrm{Fe}_{2} \mathrm{O}_{3}, \mathrm{Li}_{3} \mathrm{Fe}_{2}\left(\mathrm{PO}_{4}\right)_{3}$, and $\mathrm{Na}_{3} \mathrm{Fe}_{2}\left(\mathrm{PO}_{4}\right)_{3}$. However, adding excess $\mathrm{HNO}_{3}$ or $\mathrm{HCl}$ eliminates the $\mathrm{Fe}_{2} \mathrm{O}_{3}$ formation. Excess acid and right composition $(\mathrm{Li}(\mathrm{I}): \mathrm{Fe}(\mathrm{II})$ or $\mathrm{Fe}(\mathrm{III}): \mathrm{PA} 3: 2: 3$ in the initial $\mathrm{Fe}(\mathrm{II})$ or $\mathrm{Fe}(\mathrm{III})$ solutions) yields mesoporous $\mathrm{Li}_{3} \mathrm{Fe}_{2}\left(\mathrm{PO}_{4}\right)_{4}$. To stop the formation of the sodium phases (NaMPs) and eliminate $\mathrm{Na}^{+}$ion exchange $\left(\mathrm{Na}^{+}\right.$contamination), an appropriate substrate (such as quartz, alumina or silicon etc, resist to high temperature and free of $\mathrm{Na}$ ) must be used.

The mesoporous LMPs were further investigated using electrochemical methods to understand the reaction towards lithium of both the amorphous LMP and crystalline $o$-LiMPO ${ }_{4}$ of all metals (Mn(II), $\mathrm{Fe}(\mathrm{II}), \mathrm{Co}(\mathrm{II})$, and $\mathrm{Ni}(\mathrm{II}))$. The amorphous phases showed very low charge capacities but crystalline $\mathrm{o}-\mathrm{LiCoPO}_{4}$ and a mixture of mixed Fe(III) sample displayed around 110 and
$93 \mathrm{mAh} \cdot \mathrm{g}^{-1}$ charge capacities, respectively. Even though the LFeP samples were not pure, they show high durability. However, both o-LiMnPO${ }_{4}$ and $\mathrm{LNiPs}$ showed very low charge capacities. All mesoporous LMPs and NaMPs need further investigations to understand their applications in the synthesis of energy storage materials.

\section{Experimental Section}

\section{General Method}

$10 \mathrm{ml}$ clear aqueous solutions of $\mathrm{LiNO}_{3}:\left[\mathrm{M}\left(\mathrm{OH}_{2}\right)_{6}\right]\left(\mathrm{NO}_{3}\right)_{2}$ (where $\mathrm{M}$ is $\mathrm{Mn}(\mathrm{II}), \mathrm{Fe}(\mathrm{II}), \mathrm{Co}(\mathrm{II})$, and $\mathrm{Ni}(\mathrm{II})): \mathrm{H}_{3} \mathrm{PO}_{4}(\mathrm{PA})$ :surfactant (P123) were first prepared. The $\mathrm{Li}: \mathrm{M}(\mathrm{II}): \mathrm{H}_{3} \mathrm{PO}_{4}$ mole ratio was kept 1 and the acid/P123 mole ratio has been varied from 30 to 90 mole ratio, by 30 increments.

\section{Preparation of Salt-Surfactant Solutions (Solution A)}

Solution A contains salts, half of the required surfactant and $5 \mathrm{ml}$ of water. For a typical solution of $30 \mathrm{Li}-30 \mathrm{Ni}-\mathrm{P} 123$ (solution $\mathrm{A} 1$ ), $359.7 \mathrm{mg} \mathrm{LiNO}{ }_{3}, 1517 \mathrm{mg}\left[\mathrm{Ni}\left(\mathrm{OH}_{2}\right)_{6}\right]\left(\mathrm{NO}_{3}\right)_{2}$, and $500 \mathrm{mg}$ P123 were dissolved in $5 \mathrm{ml}$ deionized water. The solution was stirred until all ingredients become completely dissolved (typically 6-8 hrs). The same procedure was used for the other conditions using the amounts of ingredients described in Table S1.

\section{Preparation of Acid-Surfactant Solutions (Solution B)}

Solution $B$ contains $P A$, the other half of $P 123$, and deionized water. For 30PA-P123 solution (B1), $600 \mathrm{mg}$ of $85 \%$ PA and $500 \mathrm{mg}$ of $\mathrm{P} 123$ were dissolved in $5 \mathrm{ml}$ deionized water. The solution was stirred until it becomes a clear solution (typically 3-4 hrs). For the other conditions, the PA amount was doubled (B2: $1200 \mathrm{mg}$ PA) and tripled (B3: $1800 \mathrm{mg} P A$ ), respectively, while keeping the P123 and water amount the same as B1.

\section{Preparation of the Mixtures and Coating}

Corresponding solutions $\mathrm{A \#}$ and $\mathrm{B} \#$ were mixed and stirred for 1 day to obtain clear homogeneous solutions, see Figure S9. Then, each homogeneous solution was coated by either spin coating (typically at $1500 \mathrm{rpm}$ for $10 \mathrm{sec}$ ) or drop-cast coating over glass substrates or petri dishes, respectively, for further heat treatments. The films were labelled as FM30, FM60, FM90 ( $F$ stands for film, M is $\mathrm{Mn}, \mathrm{Fe}, \mathrm{Co}$, or $\mathrm{Ni}$, and \# is $\mathrm{PA} / \mathrm{P} 123$ mole ratio (or Li(I)/P123 or $\mathrm{M}(\mathrm{II}) /$ $\mathrm{P} 123$ mole ratios that are the same as PA/P123). Drop cast-coated samples are labelled as DM\#, D is used in place of $F$ for drop-cast coated samples, see Figure S9.

\section{Calcination and Annealing}

Above films (gel like) were calcined at different temperatures $\left(300^{\circ} \mathrm{C}\right.$ or $500^{\circ} \mathrm{C}$ ) by putting into preheated furnace for $1 \mathrm{hr}$. The further annealing was carried out at $500^{\circ} \mathrm{C}$ for $1 \mathrm{hr}$. All heat treatments were carried air condition. The duration of calcination and annealing was also $1 \mathrm{hr}$ in the samples prepared by drop-cast coating method. 


\section{Characterization}

A Rigaku Miniflex diffractometer equipped with a $\operatorname{CuK}_{\alpha}(\lambda=$ $1.5405 \AA$ A $)$-rays source, operating at $30 \mathrm{kV} / 15 \mathrm{~mA}$ and a Scintillator Nal (T1) detector with a Be window was used for the small angle $\left(1-5^{\circ}\right)$ measurements of the gels on the glass microscope slides. For the powder samples, Pananalytical Multipurpose X-ray diffractometer equipped with a $\mathrm{CuK}_{\alpha}(\lambda=1.5405 \AA) \mathrm{X}$-rays source, operating at $45 \mathrm{kV} / 40 \mathrm{~mA}$ was used for the wide angle $\left(10-80^{\circ}\right)$ measurements. A Bruker Alpha Platinum ATR-IR spectrometer with a Digi Tect TM DLATGS detector was used for the ATR-IR spectra with a resolution of $4 \mathrm{~cm}^{-1}$ and 64 scans in $400-4000 \mathrm{~cm}^{-1}$ range. The spectra were measured by putting a few drops of the solution for the gel phase or a powder sample on the diamond ATR crystal. The transmittance electron microscope (TEM) images were recorded on a FEl Technai G2 F30 at an operating voltage of $200 \mathrm{kV}$. The samples were scraped and grinded well in a mortar using $5 \mathrm{ml}$ of absolute ethanol and dispersed using a sonicator for $30 \mathrm{~min}$. A few drops of dispersed solution were put on a TEM grid and heated under powerful light for drying. The $\mathrm{N}_{2}$ sorption $(77.4 \mathrm{~K}$ ) measurements were carried using a Micromeritics Tristar 3000 automated gas adsorption analyser, in a relative pressure range $P / P_{0}$, from 0.01 to 0.99 over $5 \mathrm{~min}$ intervals. The powder samples collected by scraping from the glass slides were dehydrated under vacuum (35$40 \mathrm{mTorr}$ ) for $2 \mathrm{hrs}$ at $200^{\circ} \mathrm{C}$ before the $\mathrm{N}_{2}$ adsorption-desorption measurement. The electrodes were prepared by coating slurries containing the $\mathrm{LiMPO}_{4}(80 \mathrm{wt} . \%)$, a conducting agent (Super-P, $10 \mathrm{wt} . \%)$, and poly(vinylidene fluoride) (PVDF, $10 \mathrm{w} \%$ ) dissolved in NMP on Al foil with a mass loading of $\sim 2.2 \mathrm{mg} \mathrm{cm}^{-2}$. The electrodes were dried at $120^{\circ} \mathrm{C}$ for $12 \mathrm{~h}$ in a vacuum oven. The electrochemical performance was examined by assembling CR2032 coin-type half cells in an Ar-filled glove box with a polyethylene (PE) membrane. $\mathrm{Li}$ metal was used for the counter and reference electrodes. The electrolyte was composed of $1 \mathrm{M} \mathrm{LiPF}_{6}$ dissolved in a mixed solvent of ethylene carbonate (EC) and ethyl methyl carbonate (EMC) $(3: 7$ $\mathrm{v} / \mathrm{v})$. The cells were galvanostatically charged $\left(\mathrm{Li}^{+}\right.$insertion) and discharged ( $\mathrm{Li}+$ extraction) at a constant current of $20 \mathrm{~mA} / \mathrm{g}$ in a voltage window of $2.0-5.4 \mathrm{~V} \mathrm{vs}$. $\mathrm{Li}^{\prime} \mathrm{Li}^{+}$at room temperature.

\section{Acknowledgements}

We would like to thank to beam line scientist, Dr. M. Harfouche (from SESAME), Mr. K. E. Ercan and Ms. I. Karakaya for their helps in XANES and Mr. M. Güler for TEM measurements. We also thank to TÜBITAK (under the project number 215Z193) for the financial support of this work and Turkish Atomic Agency for the travel grant for the XANES measurements. This work was also performed in part at the Queensland node of the Australian National Fabrication Facility, a company established under the National Collaboration Research Infrastructure Strategy to provide nano and microfabrication facilities for Australia's researchers. Ö.D. is a member of the Science Academy, Istanbul, Turkey.

\section{Conflict of Interest}

The authors declare no conflict of interest.
Keywords: electrochemical energy storage - lithium ion batteries - lithium metal phosphates - lyotropic liquid crystals . mesoporous

[1] C. T. Kresge, M. E. Leonowicz, W. J. Roth, J. C. Vartuli, J. S. Beck, Nature 1992, 359, 710-712.

[2] T. Yanagisawa, T. Shimizu, K. Kuroda, C. Kato, Bull. Chem. Soc. Jpn. 1990, 63, 988-992.

[3] D. Zhao, J. Feng, Q. Huo, N. Melosh, G. H. Fredrickson, B. F. Chmelka, G. D. Stucky, Science 1998, 279, 548-552.

[4] H. P. Lin, C. Y. Mou, Acc. Chem. Res. 2002, 35, 927-935.

[5] H. Yang, N. Coombs, G. A. Ozin, Nature 1997, 386, 692-695.

[6] A. S. Poyraz, Ö. Dag, J. Phys. Chem. C 2009, 113, 18596-18607.

[7] H. Yang, A. Kuperman, N. Coombs, S. Mamiche-Afara, G. A. Ozin, Nature 1996, 379, 703-705.

[8] G. S. Attard, J. C. Glyde, C. G. Göltner, Nature 1995, 378, 366-368.

[9] T. Asefa, M. J. MachLachlan, N. Coombs, G. A. Ozin, Nature 1999, 402, 867-871.

[10] D. M. Antonelli, J. Yang, Angew. Chem. Int. Ed. 1995, 34, 2014-2017.

[11] W. C. Li, A. H. Lu, C. Waidenthaler, F. Schüth, Chem. Mater. 2004, 16, 5676-5681.

[12] Y. Wan, D. Zhao, Chem. Rev. 2007, 107, 2821-2860.

[13] I. Vamvasakis, K. S. Subrahmanyam, M. Kanatzidis, G. S. Armatas, ACS Nano 2015, 9, 4419-4426.

[14] B. Tian, X. Liu, B. Tu, C. Yu, J. Fan, L. Wang, S. Xie, G. D. Stucky, D. Zhao, Nat. Mater. 2003, 2, 159-163.

[15] E. Tunkara, Ö. Dag, Eur. J. Inorg. Chem. 2016, 13-14, 2114-2121.

[16] P. Mei, Y. V. Kaneti, M. Pramanik, T. Takei, Ö. Dag, Y. Sugahara, Y. Yamauchi, Nano Energy 2018, 52, 336-344.

[17] X. M. Liu, S. L. Zhang, M. Yang, X. Z. Liao, H. Yang, X. D. Shen, Z. F. Ma, Chem. Commun. 2014, 50, 15247-15250.

[18] M. Paramanik, R. R. Salunkhe, M. Imura, Y. Yamauchi, ACS Appl. Mater. Interfaces 2016, 8, 9790-9797.

[19] C. Liu, F. Li, L. P. Ma, H. M. Chang, Adv. Mater. 2010, 22, E28-E62.

[20] X. Y. Yu, L. Yu, X. W. Luo, Adv. Energy Mater. 2015, 6, 1501333(14).

[21] H. Liu, R. Zhou, B. Sun, G. Wang, S. Z. Qiao, Adv. Energy Mater. 2012, 2, 970-975.

[22] M. R. Gao, Y. F. Xu, J. Jiang, S. H. Yu, Chem. Soc. Rev. 2013, 42, 29863017.

[23] L. Mercier, T. J. Pinnavaia, Adv. Mater. 1997, 9, 500-503.

[24] T. Wagner, S. Haffer, C. Weinberger, D. Klaus, M. Tiemann, Chem. Soc. Rev. 2013, 42, 4036-4053.

[25] C. Perego, R. Millini, Chem. Soc. Rev. 2013, 42, 3956-3976.

[26] Y. Ren, A. R. Armstrong, F. Jiao, P. G. Bruce, J. Am. Chem. Soc. 2010, 132, 996-1004.

[27] K. Ariga, A. Vinu, Y. Yamauchi, Q. Ji, J. P. Hill, Bull. Chem. Soc. Jpn. 2012, $85,1-32$.

[28] B. Kang, G. Ceder, Nature 2009, 458, 190-193.

[29] B. Scrosati, J. Garche, J. Power Sources 2010, 195, 2419-2430.

[30] A. Manthiram, J. Phys. Chem. Lett. 2011, 2, 176-184.

[31] D. Yang, Z. Lu, X. Rui, X. Huang, H. Li, J. Zhu, W. Zheng, Y. M. Lam, H. H. Hng, H. Zhang, Q. Yan, Angew. Chem. Int. Ed. 2014, 53, 9352-9355.

[32] G. Wang, H. Liu, J. Liu, S. Qiao, G. M. Lu, P. Munroe, H. Ahn, Adv. Mater. 2010, 22, 4944-4948.

[33] S. Y. Chung, J. T. Bloking, Y. M. Chiang, Nat. Mater. 2002, 1, 123-128.

[34] C. Masquelier, L. Croguennec, Chem. Rev. 2013, 113, 6552-6591.

[35] S. Zhu, H. Zhou, T. Miyoshi, M. Hibino, I. Honma, M. Ichihara, Adv. Mater. 2004, 16, 2012-2017.

[36] Y. Fang, L. Xiao, J. Qian, X. Ai, H. Yang, Y. Cao, Nano Lett. 2014, 14, 3539-3543.

[37] M. Pramanik, Y. Tsujimoto, V. Malgras, S. X. Dou, J. H. Kim, Y. Yamauchi, Chem. Mater. 2015, 27, 1082-1089.

[38] B. P. Bastakoti, Y. Li, S. Guragain, M. Pramanik, S. A. Alshehri, T. Ahamad, Z. Liu, Y. Yamauchi, Chem. Eur. J. 2016, 23, 7463-7467.

[39] E. Tunkara, C. Albayrak, E. O. Polat, C. Kocabas, Ö. Dag, ACS Nano 2014, 8, 11007-11012.

[40] Ö. Çelik, Ö. Dag, Angew. Chem. Int. Ed. 2001, 40, 3800-3803.

[41] A. F. Demirörs, B. E. Eser, Ö. Dag, Langmuir 2005, 21, 4156-4162.

[42] G. Barım, C. Albayrak, E. Yılmaz, Ö. Dag, Langmuir 2014, 30, 6938-6945.

[43] F. Sanz, C. Parada, J. M. Rojo, C. Ruiz-Valero, Chem. Mater. 2001, 13, 1334-1340.

[44] H. Kim, I. Park, D. H. Seo, S. Lee, S. W. Kim, W. J. Kwon, Y. U. Park, C. S Kim, S. Jeon, K. Kang, J. Am. Chem. Soc. 2012, 134, 10369-10372. 
[45] S. M. Wood, C. Eames, E. Kendrick, M. S. Islam, J. Phys. Chem. C 2015 $119,15935-15941$.

[46] M. Avdeev, Z. Mohamed, C. D. Ling, J. Lu, M. Tamaru, A. Yamada, P. Barpanda, Inorg. Chem. 2013, 52, 8685-8693.

[47] B. Senthilkumar, K. V. Sankar, L. Vasylechko, Y. S. Lee, R. K. Selvan, RSC Adv. 2014, 4, 53192-53200.

[48] A. A. Salah, P. Jozwiak, K. Zaghib, J. Garbarczyk, F. Gendron, A. Mauger, C. M. Julien, Spectrochim. Acta Part A 2006, 65, 1007-1013.
[49] O. Haas, A. Deb, E. J. Cairns, A. Wokaun, J. Electrochem. Soc. 2005, 152, A191-A196.

Manuscript received: July 11, 2019

Revised manuscript received: August 26, 2019

Accepted manuscript online: August 28, 2019 